\title{
Community Based Peat Conservation
}

\author{
Konservasi Gambut Berbasis Masyarakat
}

\author{
Arman Manalu ${ }^{1 *}$ \\ ${ }^{1}$ Balai Besar Wilayah Sungai Citarum, Bandung \\ ${ }^{*}$ Corresponding author: arman_manalu@yahoo.com
}

(Received: 18 September 2019, Accepted: 24 March 2020)

Cititation: Manalu A. 2020. Community based peat conservation. Jurnal Lahan Suboptimal: Journal of Suboptimal Lands 9(1): 11-22.

\begin{abstract}
ABSTRAK
Gambut terbentuk secara alami di daerah rawa saat tanaman mati membusuk dan menumpuk yang kemudian terdekompresi dan terakumulasi dalam kurun waktu ratusan sampai ribuan tahun. Gambut dapat menyimpan karbon 20 kali lebih banyak dari pada tanah mineral. Lahan gambut Indonesia menyimpan sekitar 46 Gt karbon atau sekitar 8-14 $\%$ dari karbon gambut dunia (Maltby dan Immirizi, 1993). Gambut memiliki ekosistim penting yang bertidak sebagai pelindung atmosfer bumi dari efek rumah kaca, penyangga ekologi dan meyimpan keanekaragaman hayati serta tempat bermukim berbagai flora fauna. Gambut mempunyai kemampuan menyerupai spon yang menjadikannya cocok sebagai kawasan resapan air. Tujuan penelitian ini adalah untuk memberikan gambaran akan pentingnya menjaga dan memelihara lahan gambut sebagai pelindung atmosfer bumi, pengendali iklim global dengan melibatkan masyarakat. Penelitian ini dilakukan dengan metode deskriftif kualitatif yang diambil dari berbagai literatur dan media nasional. Hasil penelitian menunjukkan bahwa telah terjadi degradasi lahan akibat alih fungsi lahan gambut secara luas menjadi perkebunan yang dalam prosesnya menyebabkan kerusakan lingkungan dan ekosistim gambut di berbagai wilayah Indonesia. Untuk itu perlu dilakukan konservasi gambut berbasis masyarakat agar keberlangsungnnya dapat terjaga dan masyarakat sekitar mendapat manfaat ekonomi dari lahan gambut.
\end{abstract}

Kata kunci: gambut, ekosistim, konservasi

\begin{abstract}
Peat forms naturally in swamp areas when dead plants rot and accumulate, which then decompresses and accumulates within hundreds to thousands of years. Peat can store 20 times more carbon than mineral soil. Indonesia's peatlands store about $46 \mathrm{Gt}$ of carbon or around $8-14 \%$ of world peat carbon (Maltby and Immirizi, 1993). Peat has an important ecosystem that acts as a protector of the Earth's atmosphere from the greenhouse effect, ecological buffer, saves biodiversity and a place to live for various flora and fauna. Peat have the ability to resemble sponges which make them suitable as water catchment areas. The purpose of this study is to provide an overview of the importance of protecting and maintaining peatlands as protectors of the Earth's atmosphere, controlling global climate by involving the community. This research was conducted with qualitative descriptive methods taken from various literature and national media. The results showed that land degradation has occurred due to the extensive conversion of peatlands into plantations
\end{abstract}


which in the process of causing environmental damage and peat ecosystems in various regions of Indonesia. For this reason, community-based peat conservation needs to be done so that sustainability is maintained and the community gets economic benefits from peatlands.

Keywords: peat, ecosystem, conservation

\section{INTRODUCTION}

Peat forms naturally when organic material from various plants, trees, leaves and animal bodies decays and accumulates in swampy areas and decomposes and accumulates over hundreds to thousands of years. Basically the organic material is not completely decomposed, becouse there is not enough oxygen to carry out the decay process due to being constantly submerged in water. The requirements for peat formation are the presence of damped and saturated organic matter, low oxygen and high acidity. The carbon stock below the surface of peatlands is much higher than above the surface of mineral land (Figure 1). Ecologically peatlands store carbon reaching 20 (twenty) times more than nonpeat mineral soils. Demographically, Indonesia is home to around 36 (thirty six) $\%$ of the world's tropical peatlands. Peatlands in Indonesia store around $46 \mathrm{Gt}$ of carbon or around $8-14 \%$ of peat carbon in the world (Maltby and Immirizi, 1993). Peat has an important ecosystem that functions as a protector of the Earth's atmosphere from the release of greenhouse gas elements and global climate control. Peat also serves to maintain the balance of nature such as flood control, water management, ecological buffering, as a habitat for various species of living things. Peat forests are also a source of germplasm, wood and so on which are sources of community livelihood. Peat has the ability to resemble a sponge that makes it suitable as a water catchment area by absorbing, holding and storing water in the rainy season and regulating water inside and the surface of the soil, and then releasing it slowly continuously in the dry season. Peatlands can be used for aquaculture, aqriculture with certain productive plants, although management is not easy. Given the enormous benefits, we should treat peat wisely and be able to cultivate and manage peatlands for economic purposes while maintaining the ecosystem. In Indonesia, peatlands have been largely transformed into large plantations with monocultures. Many peatlands have been damaged due to land management without regard to the sustainability of the environmentally friendly peat ecosystem. In Kalimantan in the past, a million hectares of peatland was cleared for rice crops which ended in failure and left a very severe environmental damage and caused local communities to suffer. Canalization and cutting of peat domes with the intention of draining the land has damaged the water system and the peatland hydrological system (Figure 2). Peat burning methods to speed up land clearing by companies and communities who want to develop oil palm plantations also contribute to environmental damage. Burning peat will produce smoke and carbon emissions that enter the atmosphere and can cause eye irritation, respiratory infections and lungs. smoke pollution also covers the air of Sumatra, Kalimantan to Malaysia and Singapore, thus endangering the aviation world which results in several airports having to be closed.

The government has taken steps to repair the damage and improve peatland management by issuing a Presidential Regulation (PERPRES) No.01 of 2016 concerning the establishment of a Peat Restoration Agency (BRG) which is given a mandate and authority to coordinate and facilitate the restoration of peatlands covering an area of 2 (two) million hectares located in 7 (seven) provinces until 2020. For this reason, BRG has launched three main pillars, namely:

1. Rewetting of peat 
2. Revegetation(Restoration/ rehabilitation of vegetation)

3. Revitalisation of local livelihoods

The purpose of this study is intended to provide an overview of the importance of maintaining and preserving peatlands as a protector of the Earth's atmosphere, controlling global climate by involving the community. So that the community will also get economic benefits, improve living standards in an effort towards a better and healthier life.

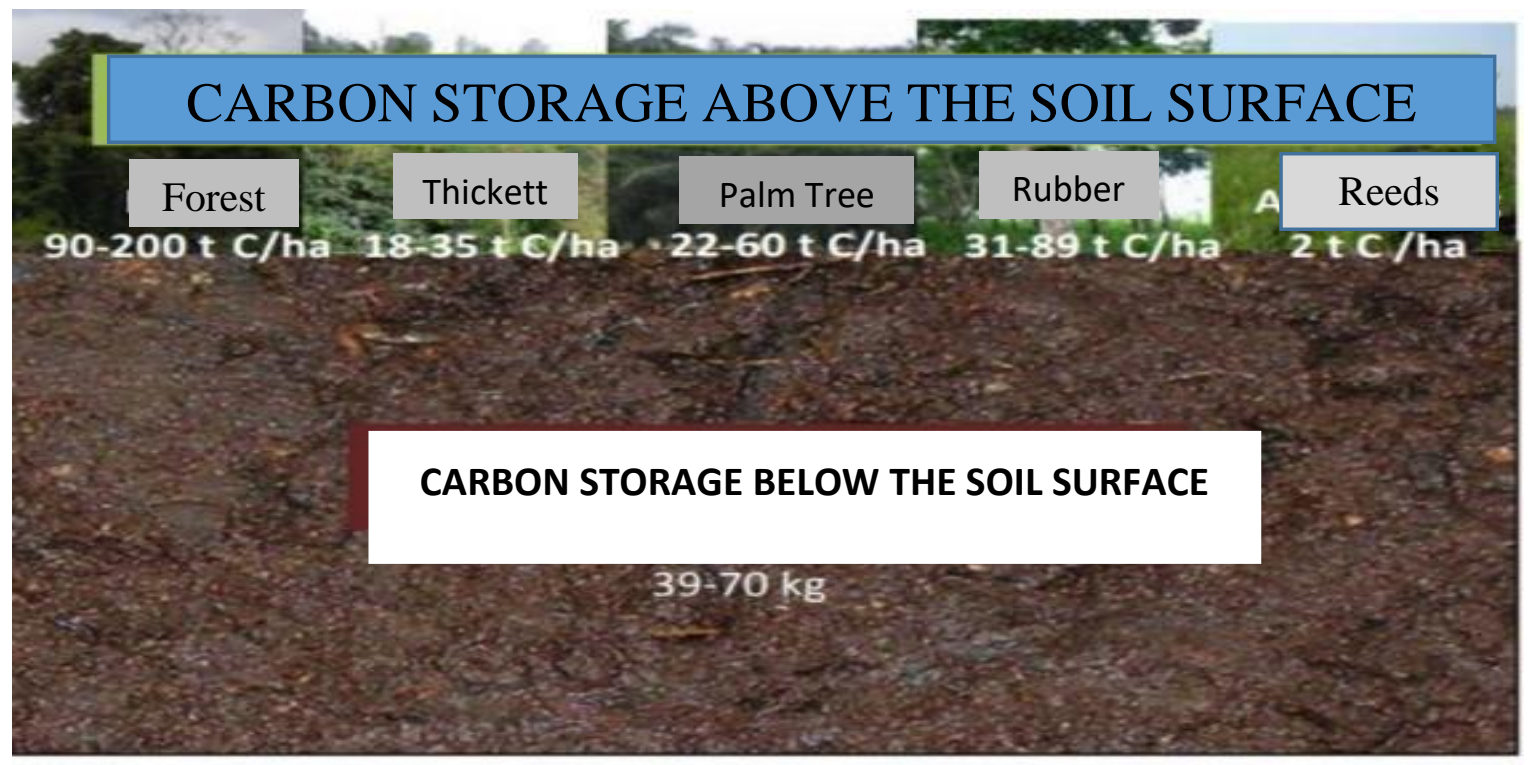

Figure 1. Carbon deposits above ground level. Pictures can be seen in the book of "Lahan gambut Indonesia, Pembentukan, Karakteristik dan mendukung ketahanan pangan”, revised edition, by Balitbangtan, Ministry of Agriculture. 2016. Page 103
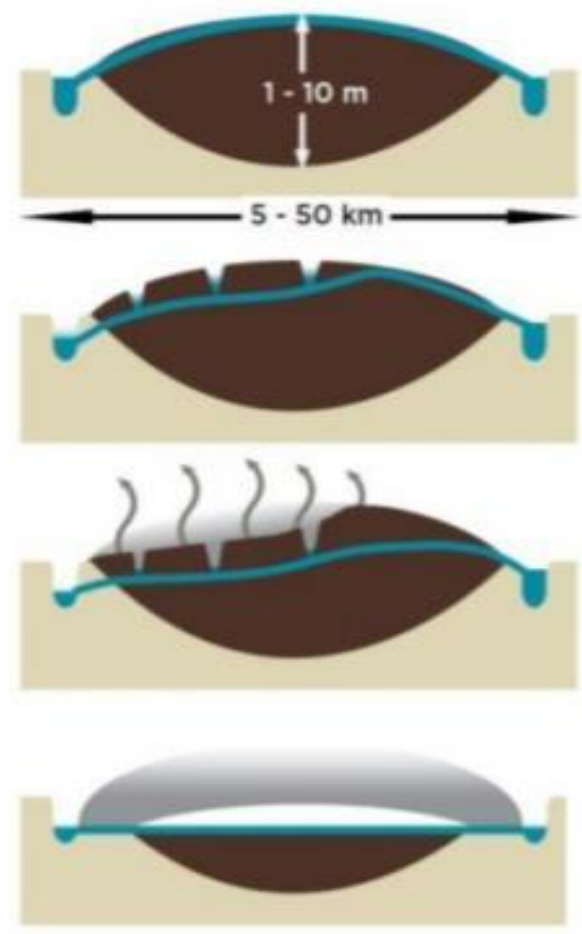

\section{Natural Conditions}

- Ground water level close to the surface of the peat

- $\quad$ peat accumulation from plants

Drainage

- Decrease in ground water level

- Peat subsidence due to compaction and consolidation

- $\mathrm{CO}_{2}$ emissions begin

Drainage continues

- Peat decomposition. more $\mathrm{CO}_{2}$ is released

- High risk of fire. more $\mathrm{CO}_{2}$ is released

- Peat subsidence mainly due to decomposition

Final stage

- Most of the peat above the drainage limit has been released into the atmosphere for decades Surface, dome, clay, flow canal, peat dome

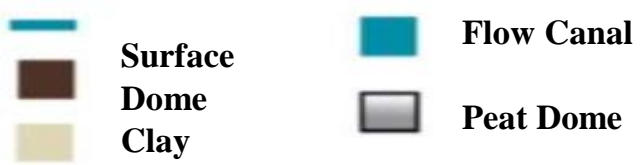

Figure 2. Land subsidence process. The picture can be seen in the book of "Tropical Peatlands " , University of Leicester, page 35 


\section{MATERIALS AND METHODS}

This research method was carried out with a literature study whose data was taken from various related agency sources, including the Ministry of Environment, Ministry of Forestry, Research Institution, Walhi, Wetlands and other news sources. Data analysis was performed descriptively qualitative.

\section{RESULTS AND DISCUSSION}

Peat conservation and restoration programs carried out by the government and the private sector have ended in failure because they only focus on restoring ecological functions, but neglecting the needs of local communities to survive. For example, when the government wants to make a partition or some kind of small dam that aims to raise the water level to keep peat wet, but does not provide any benefit to the community, so the community will drain it back for agricultural land. Peatland conservation by involving the community that has been carried out by various parties can actually reduce the rate of peat damage, maintain peat conservation, provide economic benefits and improve the standard of living of the community.

\section{Distribution and Area of Peatlands}

Broadly speaking, peatlands in Indonesia are spread over 3 (three) islands, namely; Sumatra, Kalimantan and Papua. However, the total area is not yet known with certainty, each agency and researcher presents different data and changes or differences in data can also mean peatland shrinkage has occured. In 2008 Balitbangtan, the Ministry of Agriculture issued data on peatlands and their distribution in various provinces which can be seen in table 1. In 2008 the Agricultural Development Research Agency released data on peatlands and their distribution in various provinces which can be seen in Table 2. In 2013 the Agriculture Research and Development Agency of the
Agriculture Ministry issued data on the distribution of peat and its land cover and conditions which can be seen in Table 3 .

\section{Peat Types and Characteristics}

In the book "'Strategi pengelolaan lahan gambut (KLH. 2012)")", it states that there are various types of peat, namely:

a) Lake peat swamps, back swamps of large river embankments (backswamp). Lake Peat Swamp Lake is commonly called inland peat that is on land and is formed from various conditions such as the former Volcanic crater (volcanic crater), horseshoe lake (oxbow lake), lake in the karst system (sinkhole, doline), lakes as part of structural systems such as folding (folding system). The eco-functional boundary of peat in this lake swamp system is the lake boundary itself.

b) Swampy peat, which is part of a watershed system (DAS). The boundaries of the eco-functional area are the main river embankments, creeks on either side, and land.

c) Coastal peat swamps are formed as a result of sea level rise (transgression), with boundaries between land and sea. In the coastal swamp system there are rivers that are interconnected with one another, so that it is possible to have an island or delta bordering rivers, or rivers with the sea. Generally peat in Indonesia is peat in coastal swamps, which are spread on the east coast of Sumatra, the west and south coast of Kalimantan, and on the south coast of Papua (Figure 3).

Characteristics of peatlands include a variety of physical, namely; weight and thickness of the peat, peat maturity, hydrotopography, hydraulic conductivity, and sediment under the peat. Peat in Indonesia is a tropical peat that has specific characteristics that are different from suptropical peat which is formed from sedge or moss. Tropical peat in Indonesia is rich in Lignin and Cellulose content (Andriesse, 1988). 
With the diversity of peat types, the management methods are also different according to the characteristics of each peat

so that it can be used sustainably while the ecosystem can be maintained (Table 4).

Table 1. Peatlands area. Taken from various sources

\begin{tabular}{lcc}
\multicolumn{1}{c}{ Source } & Year & Area in Million (Ha) \\
\hline Nazir Foead (BRG) & 2019 & 18.900 \\
Balittanah & 2011 & 14.900 \\
BB Litbang SDLP & 2008 & 18.317 \\
Wetlands & 2005 & 20.600 \\
Dwiyono \& Rahman & 1996 & 20.000 \\
\hline
\end{tabular}

Table 2. Total area of peatlands and that are suitable for agriculture and their distribution in Indonesia (BB Litbang SDLP., 2008).

\begin{tabular}{lrr}
\hline Island/Province & Total Area & Worthy of Agriculture \\
\cline { 2 - 3 } & (Ha) & (Ha) \\
\hline Sumatera & $\mathbf{6 . 2 4 4 . 1 0 1}$ & $\mathbf{2 . 2 5 3 . 7 3 3}$ \\
Riau & 4.043 .600 & 774.946 \\
Jambi & 716.839 & 333.936 \\
South Sumatera & 1.483 .662 & 1.144 .851 \\
Kalimantan (Borneo) & $\mathbf{5 . 0 7 2 . 2 4 9}$ & $\mathbf{1 . 5 3 0 . 2 5 6}$ \\
Central Kalimantan & 3.010 .640 & 672.723 \\
West Kalimantan & 1.729 .980 & 694.714 \\
South Kalimantan & 331.629 & 162.819 \\
Papua dan West Papua & 7.001 .239 & 2.273 .160 \\
\hline Total & $\mathbf{1 8 . 3 1 7 . 5 8 9}$ & $\mathbf{6 . 0 5 7 . 1 4 9}$ \\
\hline
\end{tabular}

Table 3. Distribution of peatlands based on land cover (BB Litbang SDLP, 2013)

\begin{tabular}{lccl}
\hline Land use & Area (Million Ha) & $\%$ & \multicolumn{1}{c}{ Information } \\
\hline Forest & 8,28 & 55,5 & Not yet degraded \\
Palm plantations & 1,54 & 10,3 & Degraded \\
Shrubs & 3,8 & 25,5 & Degraded \\
Agricultural land & 0,7 & 4,7 & Degraded \\
Former mining concessions & 0,61 & 4,1 & Severely degraded \\
\hline \multicolumn{1}{c}{ Total } & 14,93 & 100 & 100,0 \\
\hline
\end{tabular}

Table 4. Characteristics of thin to medium peat and thick peat, (Agricultural research and development agency, Ministry of Agriculture, 2016)

\begin{tabular}{llll}
\hline Type / characteristics & Thin-medium peat $(50-100 \mathrm{~cm}$ and $100-300 \mathrm{~cm})$ & Thick peat - very thick \\
\hline Peat types & Topogen (determined by basin topography) & $\begin{array}{l}\text { Ombrogen (determined by } \\
\text { rainwater and very little }\end{array}$
\end{tabular} topographic influence)

$3.1-3.9$

$\mathrm{PH}$

Decomposition

Results

Plant Respon Maturity Saprik

(The ability of plant roots) plants)

$$
3.5-4
$$

Organic acids that bind to metals, forming complexes that are relatively stable (not toxic to

The roots can penetrate/reach mineral soil layers and absorb mineral soil nutrients, and plants are more stable

$$
3.1-3.9
$$

Organic acids that are free (dissolved), are toxic to plants

Fibric or hemic

Roots cannot penetrate mineral soil layers, and plants are unstable / easy to fall Infertile

Fertility rate Fertile

Source: Book of "Pembentukan, Karakteristik dan mendukung ketahanan pangan, revised edition" Chapter 10 page 229. Agricultural Research and Development Agency of the Ministry of Agriculture 2016 


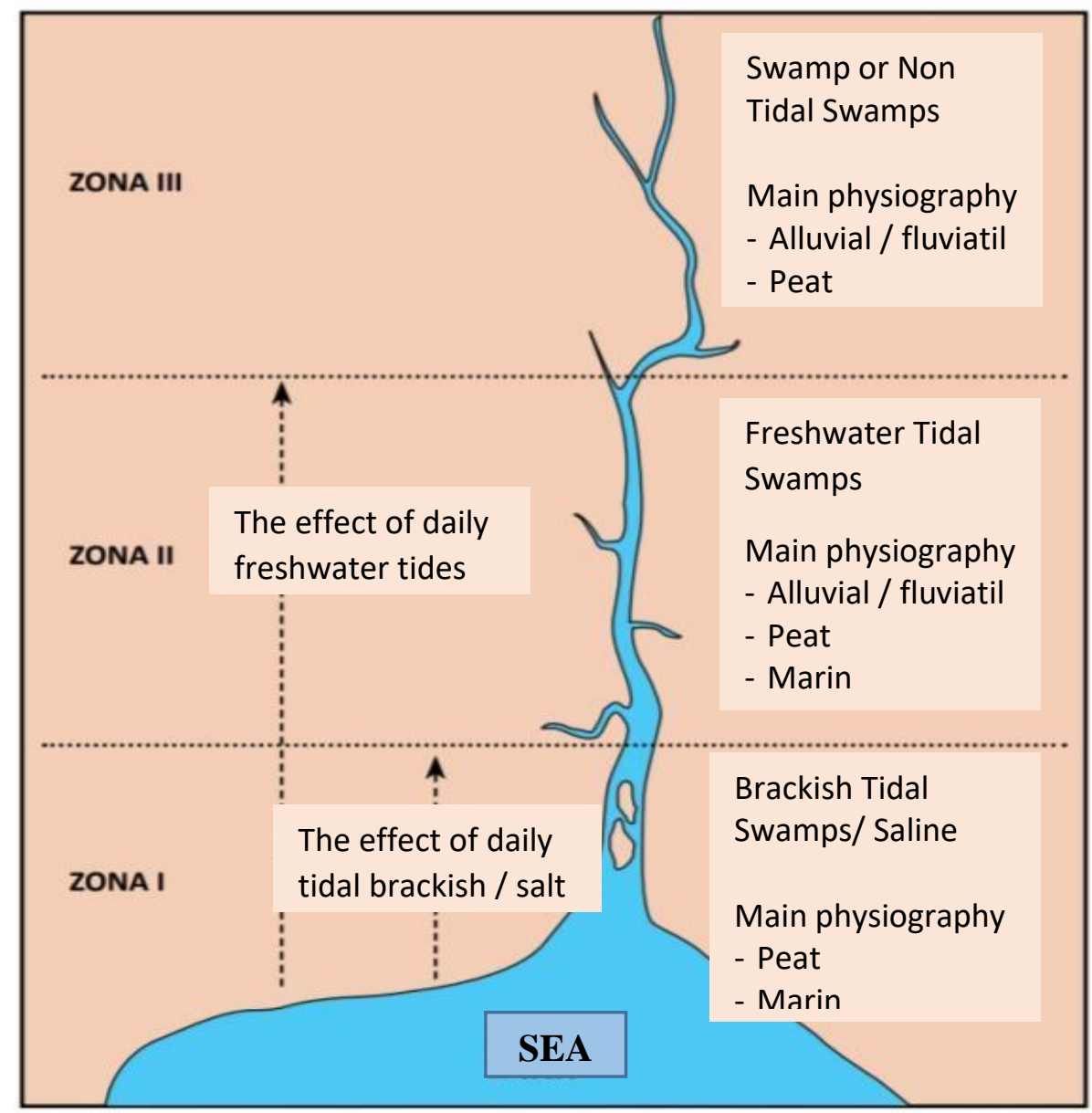

Figure 3. Division of zones in swamp landscapes is based on the influence of tidal forces and seawater intrusion coverage. (Agricultural Research and Development Agency, 2012). Source, http://www.litbang.pertanian.go.id/buku/Lahan_Rawa/BAB1.pdf

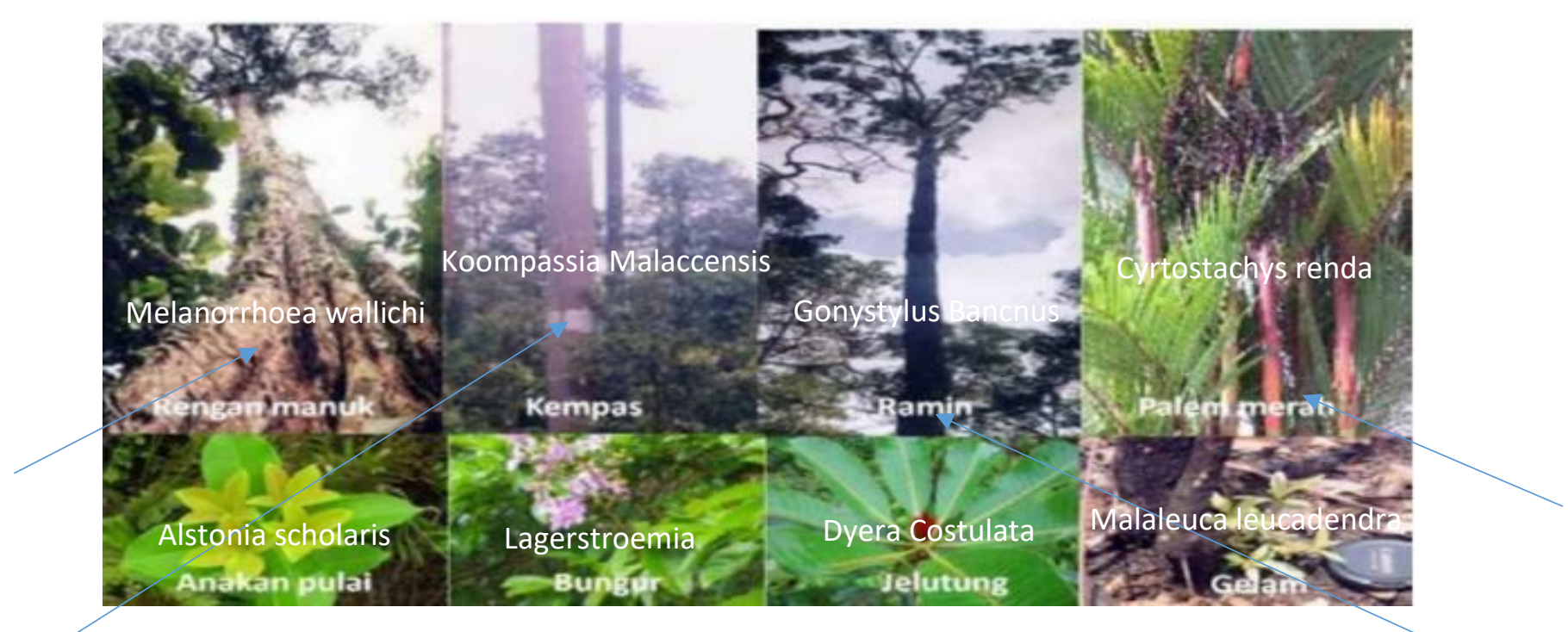

Figure 4. Some examples of plants that live on peatlands. The picture can be seen in the book "Lahan gambut Indonesia, Pembentukan, Karakteristik dan mendukung ketahanan pangan”, revised edition, Balitbangtan, Ministry of Agriculture. 2016. Chapter 5 page 110. 


\section{Peat Function}

Peat has an important ecosystem with many functions for the sustainability of human life, among others:

a. As a storehouse of carbon that acts as a controller of global climate stability, protecting the earth's atmosphere from the release of greenhouse gas elements.

b. Flood control and water management by absorbing and storing water during the rainy season and releasing it slowly in the dry season. Naturally peat can absorb and store water $300-3000 \%$ of its dry weight, far exceeding the ability of mineral soils which are only able to absorb $20-35 \%$ of its dry weight (Elon et al., 2011).

c. As a habitat for various types of flora and fauna.

d. Sources of germplasm, wood and others which are sources of income and livelihoods of the local community.

\section{e. Buffering ecology}

\section{The Economic Benefits of Peatlands}

From an economic standpoint, peat is a source of livelihood for driving the economic wheel that is promising for the community. Peat is rich in biodiversity, high-value timber and non-timber products. Some high-value economic timber products include; Dolken gelam wood, ramin (Gonystylus Bancanus), jelutung marsh (Dyera Costulata), hump (Tetramerista Glabra), bungur (Lagerstroemia Speciosa), and meranti swamp (Shorea Pauciflora). While non-timber products, among others; rattan, resin, jeluntung gum and others. Peat is also a breeding ground for fish, which is of economic value. Peatlands can also be used for farming, plantations, community cultivation and other agricultural activities. One source of food staples of traditional communities living in swamps is sago, which is widely available in the Riau Islands and Papua. Peat also provides purun grass as a high quality woven raw material, a source of extract of lignin (human Acid) chemicals which is a raw material for the cosmetics, pharmaceutical industry and there are still many economic potentials that have not been explored and utilized (Figure 4).

\section{Dangers and Impacts of Peatland Damage}

The main cause of peat damage is the burning of peatlands to speed up land clearing and drainage of peatlands by making open canals free. Basically peat in its natural conditions is difficult to burn, because it tends to get wet. The effect of fire or burning of peat forest is the loss of carbon that can cause global climate warming, excessive smoke production accompanied by the presence of various particles that limit visibility, blocking the view and disrupting flights. The impact on health is respiratory infections, difficulty breathing, lung cancer. This occurs when the hydrocarbons in the air from various compounds react with other materials or particles and form new bonds called plycyclic aromatic hydrocarbons (PAHs), which when inhaled by humans in the area affected by fires causes lung injury and stimulate the formation of cancer cells. People who are close to the location of the fire easily feel tired, sore eyes, fatigue, loss of orientation and even loss of consciousness and cause death due to lack of oxygen and too much $\mathrm{CO}$ and $\mathrm{C} 02$ gas.

Draining peat by making canals will make the peat shrink and dry out due to water loss and begin to rot, subsidence of the peat surface (Figure 5). When the peat has dried (pseudosand) it will be difficult to get wet again as before, this is because the peat is irreversible drying. Peat that is already dry will easily experience erosion, both carried by the wind and carried by the water and flammable.

The costs needed to restore peatlands that are burned and often carried out by oil palm plantation companies, pulpwood companies and agriculture will be far greater than the results obtained from taxes and others. The people who suffer from the burning are the local people, not the planters, because with the destruction of 
peatlands, the source of community income is disrupted. In 2015 there were 443,598 Ha of peat fires on the islands of Kalimantan, Sumatra and Papua (Sutopo, 2105).
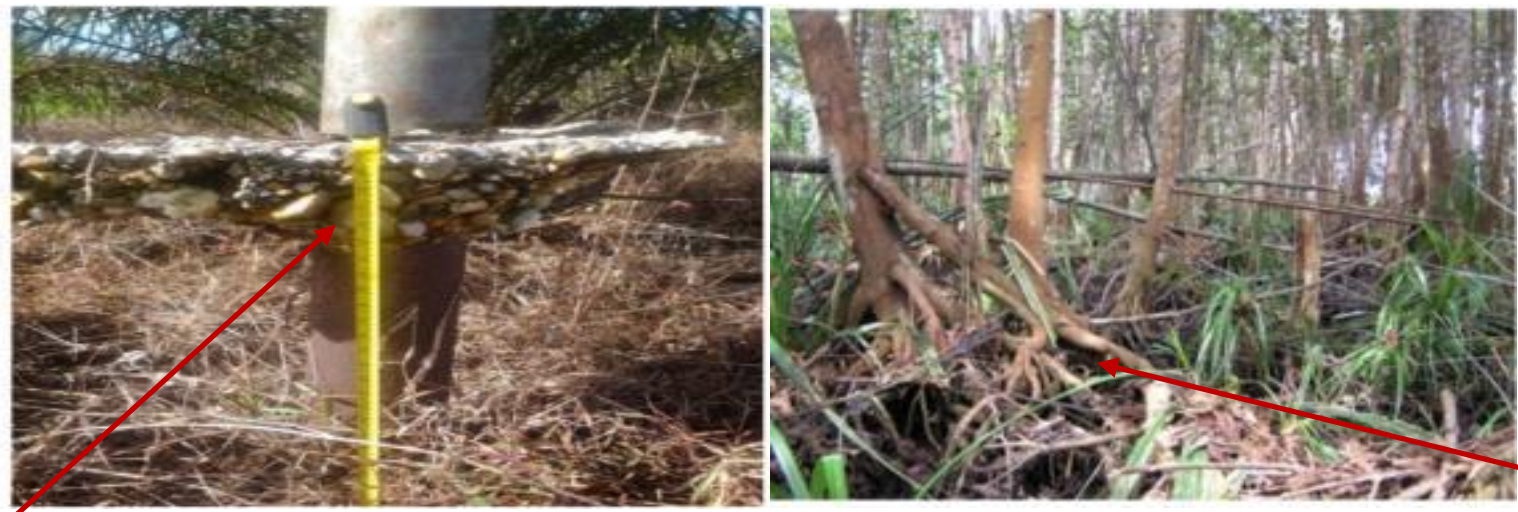

igure 5. Decline of peat surface around $90 \mathrm{~cm}$ drained over the period 9 (nine) of years (left). A hanging root indicates a subsidence. Picture can be seen in the book "Lahan gambut Potensi untuk pertanian dan aspek lingkungan, Balitbangtan, Kementan. 2008 dan "Lahan gambut Indonesia, Pembentukan, Karakteristik dan mendukung ketahanan pangan", revised edition, by Balitbangtan, Ministry of Agriculture. 2016. Chapter 10 page 230 .

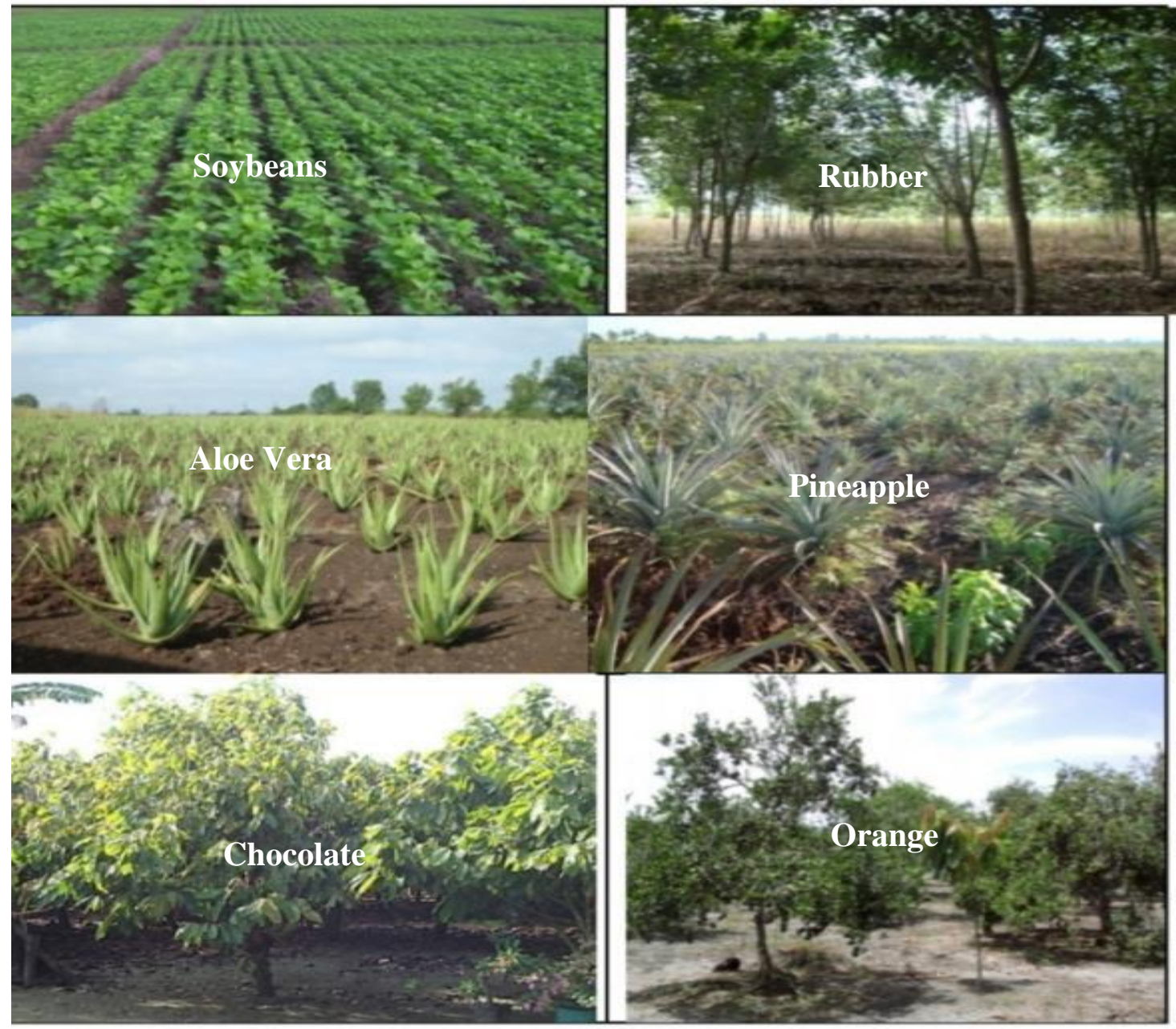

Figure 6. Cultivation of various plants in various places. Soybean and rubber in Central Kalimantan (above), aloe vera and pineapple in West Kalimantan (middle), chocolate and orange in West Sulawesi (below). Pictures can be seen in the book "Lahan gambut Indonesia, Pembentukan, Karakteristik dan mendukung ketahanan pangan”, revised edition, Balitbangtan, Ministry of Agriculture. 2016. Chapter 7 Page 169 


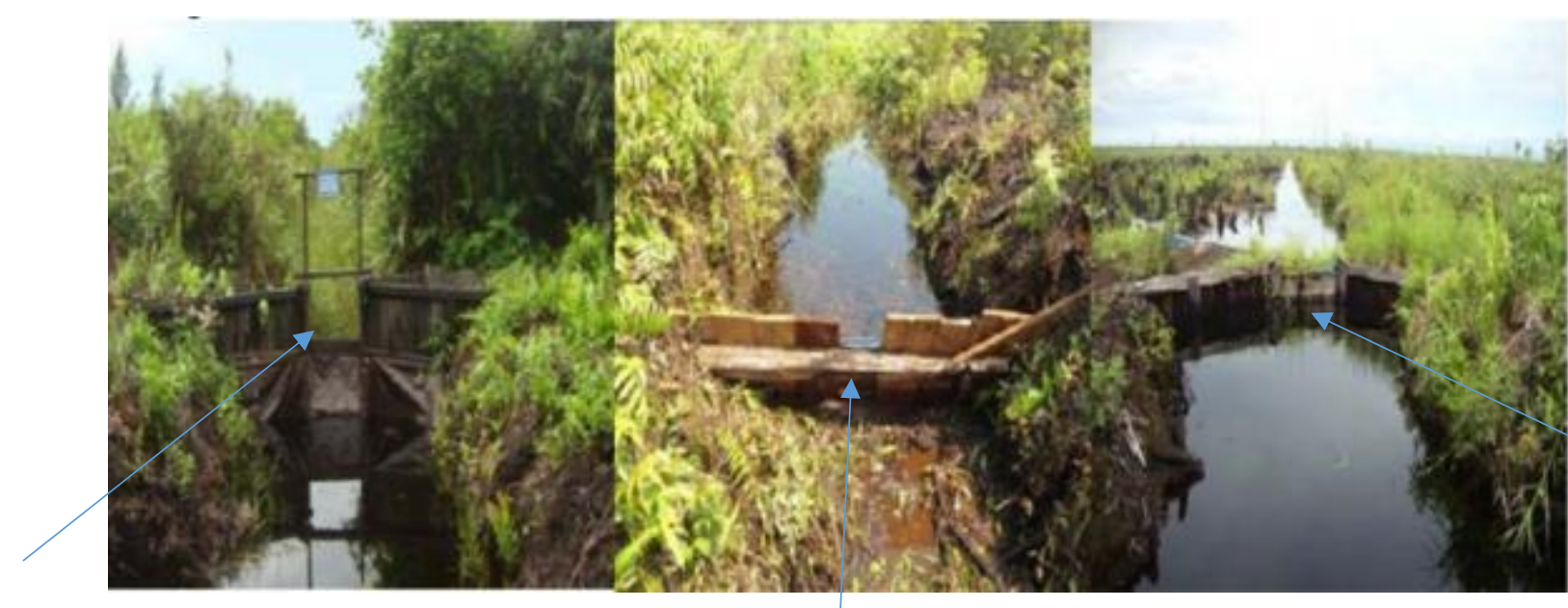

Figure 7. Simple floodgates to raise the surface of the water so that the foliage is always wet. Pictures can be seen in book of "Lahan gambut Indonesia, Pembentukan, Karakteristik dan mendukung ketahanan pangan", revised edition, Balitbangtan, Ministry of Agriculture. 2016. Chapter 6 Page 142

\section{Peat Consevation}

Peat conservation is very important to do, because many are abandoned and the amount of peatlands is shrinking. Peat conservation is very important to do, because many are abandoned and the amount of peatlands is shrinking. The thicker the peat, the more important its function for the protection and maintenance of environmental health. In its implementation, conservation must be followed by careful planning, mapping of peat problems and conditions, community habits, how to grow crops, sources of income other than planting, patterns of utilization of peatlands, whatever plants are suitable for implementation in a systematic, integrated, measurable, sustainable and at the same time able to maintain the sustainability of the peat ecosystem. For the revegetation program to run smoothly and successfully, systematic preparation and planning is needed so that all activities can be carried out successfully in the field. In its implementation, peat conservation will run optimally if it is done by involving the participation of local communities, paying attention to the suitability of plants with peatlands, supported by directed and integrated policies, appropriate technology, community assistance, strict law enforcement to prevent peatland burning (Figure 6).
It should be emphasized that once peatland is damaged, it will trigger further peat damage, because peat damage will worsen the economic condition of the community and consequently the community will enter further into conservation areas or protected forests. Peat conservation also needs to be supported by a moratorium on new land clearing for the plantation industry and restoration of degraded peatlands. The restoration program can be carried out by revegetating endemic plants or adaptive plants in wetlands to restore land cover and improve the peat ecosystem. Revegetation can be done with a surjan system and paludiculture. The surjan system is an agroforestry that does not use a drainage system which means that the peat remains in wet conditions. Paludiculture is the cultivation of plants with swamp plants or plants that can live in ever-wet land conditions. Technical and financial assistance also needs to be done to develop livelihood options, so that the community is able to leave illegal logging and manage peatland use that is not compatible with the health of the peat ecosystem. Some revegetation methods are as follows:

1. Plant endemic or adaptive seeds on peatlands.

2. Enriched planting on degraded peatlands 
3. Application of seed dispersal techniques to encourage regeneration of peat trees

4. Technical and financial assistance to develop sustainable livelihood options, so that local communities are able to abandon illegal logging activities and unsustainable peatland management.

5. Guiding the community to make simple flood gates and water management procedures so that peatlands are always wet in certain elevations so that peatlands can be planted with various vegetation (Figure 7).

\section{Counseling}

Conservation can run smoothly if the community is given an adequate understanding of peat plants, their hazards and treatment procedures through counseling and training, which include the following:

1. Understanding the dangers of land clearing by burning and the effects of peat fires on health, ecosystems and the sustainability of biodiversity and its effect on the global climate.

2. Guide the community on how to make simple flood gates to raise the water level so that peatlands can be planted with various vegetation.

3. Inviting the public to regevetation with suitable plants according to location.

4. Guide the community how how to clear land, plant seedlings, monitor and maintain plants to keep growing well.

5. Involve local community in restoration project activities funded by the government and from foreign donor agencies. Besides accommodating the workforce, it can also move the economy and improve the standard of living of the community, making people feel they have and are ready to care for them.

6. Forming groups of peat swamp forest lovers or communities that care about peat swamp sustainability, to care for, manage and restore peatlands.
7. Educate and train the community to understand peat disaster mitigation, about fire hazards, how to avoid fires, extinguishing peat fires and how to use fire equipment along with the supply of fire fighting equipment known as the Reduction of Emissions Deforestation and Forest Degradation (REDD) concept.

\section{Community Empowerment and Local Wisdom}

Basically, indigenous people in a peat area have special abilities or techniques that have been handed down for generations to manage peatlands, which have proven successful. as did the Kalimantan Dayak community, both in making traditional drainage (Tabat) and environmentally friendly farming methods (Figure 8). The government and the private sector can cooperate with local communities to carry out conservation, restoration that is environmentally sound and at the same time benefits the local community. for migrants to be guided in advance to learn special techniques so that their abilities increase. so that the implementation in the field can sinergyze with local communities in managing peatlands. It is also hoped that the government recognizes the indigenous peoples' customary rights over their customary territories so that peat forests can be preserved.

\section{Peat as an Ecotourism Place}

In terms of helping to build a people's economy in the community living in the peat swamp area, it can be done by promoting ecotourism that is environmentally friendly. Ecotourism can be offered in a combination of cultural tourism, local cuisine, conservation and adventure activities. Cultural tourism can be done by visiting historic sites, visiting historic buildings and tasting local cuisine. Then the activity continued with peat tourism, introduction of peat swamp forest and conservation and peat restoration activities (Figure 9). 


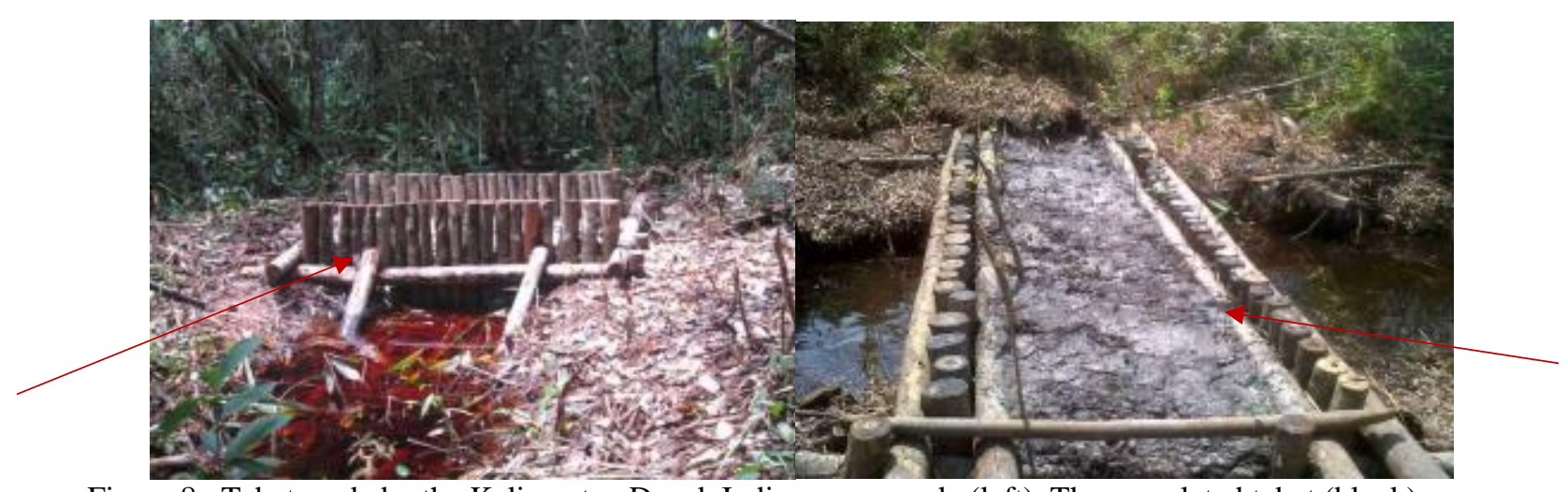

Figure 8. Tabat made by the Kalimantan Dayak Indigenous people (left). The completed tabat (block) was planted with an endemic plant (right). Images can be seen at https://orangutan.or.id/id/mawas-peatlandrehabilitation-program

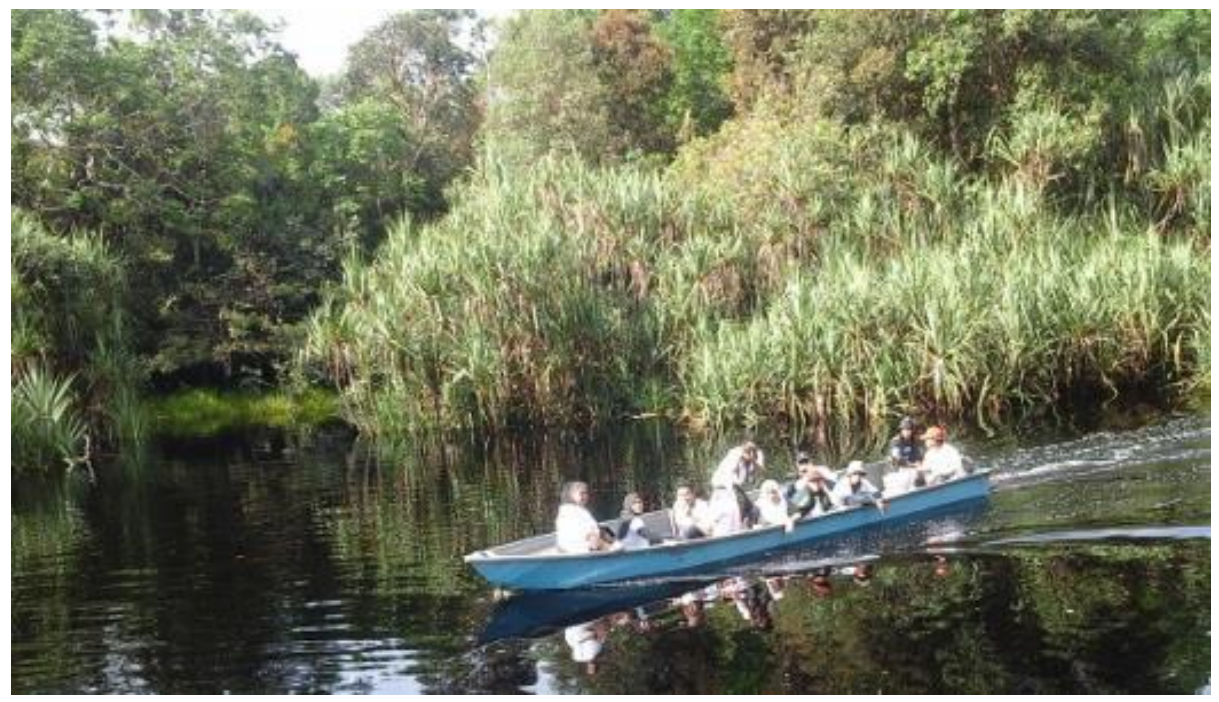

Figure 9. Ecotourism of peat swamp forests, Giam Siak Bukti Batu, Pekanbaru. Image can be seen in https://www.ekuatorial.com/id/2015/05/ekowisata-giam-siak-mulai-untungkan-penduduk/

\section{CONCLUSION}

From the above description it can be concluded, that the types and composition of peatlands are not the same and thus the handling methods are also different. Conservation without involving the community, only makes prolonged suffering and ineffective because the community does not get economic benefits, does not feel they have the burden to care for plant life. Conservation that ignores the community, will make the community enter further into the protected forest area by logging illegal and gardening without paying attention to the ecological and ecosystem damage caused by peat areas. The thicker the peat, the better it is for environmental protection, the more infertile it is for agricultureThe costs needed to restore and conserve degraded peat are far more expensive than preventing damage.

\section{REFERENCES}

Andriesse JP. 1988. Nature and Management of Tropical Peat Soils. Soil Resources, Management \& Conservation Cervice. FAO Land and Water Development Division. FAO, Rome. P 165.

Elon SV, Boelter DH, Palvanen J, Nicholas DS, Maltere T, Gafni A. 2011. Physical Properties of Organic Soils anda Francis Group, LLC. 
Maltby E, Immirzi CP. 1993. Carbon dynamics in peatlands and other wetland soils: regional and global perspectives. Chemosphere 27, 999-1023.

Ministry of Environment. 2012. National Strategy for Sustainable Management of Peatlands in Indonesia.

Peat Restoration Agency. 2017. Technical Guide to Peatland Revegetation.

ICRR Research and Development Plan. 2008. Annual report 2008. Consortium for research and development on climate change in the agriculture sector. Bogor.

Agriculture Research and Development. 2013. Map of Degraded Peatlands, scale of 1: 250,000 .

University of Leichester. Higher Geography and Biology Material for Education. https://thorntonconservation.files.wordpr ess.com/2017/12/tropical-

peatlands_their-global-importance-androle-in-the-water-and-carbon-cycles.pdf. Accessed 02 August 2019.

https://orangutan.or.id/id/mawas-peatlandrehabilitation-program/. Accessed 30 July 2019.

https://www.ekuatorial.com/id/2015/05/eko wisata-giam-siak-mulai-untungkanpenduduk/

http://balittanah.litbang.pertanian.go.id/ind/ dokumentasi/buku/booklet_gambut_final .pdf. accessed on 2 August 2019.

http://www.litbang.pertanian.go.id/buku/La han_Rawa/BAB1.pdf. Accessed on 2 August 2019. 